\title{
CONSTANTINOPLE WINE ROUTE - A NEW WINE TOURISM PROJECT IN THE BALKANS
}

\author{
Mirjana Maksimović \\ Tatjana Pivac \\ Romina Alkier
}

https://doi.org/10.20867/tosee.05.43

\begin{abstract}
Purpose - to present a new potential project in the field of wine tourism. Constantinople wine route (CWR) or Carigradski vinski drum (CVD) is a new project of wine tourism with a name and a historical significance based on its incomparably older predecessor, Constantinople road. The Constantinople Road was built by Romans in 33A.D. However, culturally speaking, CWR acquired its highest importance in the Middle Ages when it became an important trade road connecting Asia and Europe. Wine, gastronomy, and all other tourist contents were added to the Constantinople road, turning it into an attractive tourist route called simply the Constantinople Wine Route.

Methodology - for the purposes of this paper survey was conducted using the method of semistandardized interviews with owners or managers of 53 wineries on the route of the CWR. This paper contains analysis of all the content required for the development of a new wine route, based on the interview of all potential service providers and the available data.

Findings - different parts of the CWR provide various contents when wine tourism and wine offer are concerned. The route is rich in good and worldwide award-winning wines, which is extremely important for professionals and top wine experts. The tourist infrastructure can be considered acceptable, though not ideal.

Contribution - This paper has a significant contribution because it offers a proposal for the establishment of a new wine road - Constantinople wine route, which can connect several countries. Due to the lack of adequate theoretical and scientific literature dealing with this topic, this paper can be useful for anyone interested in wine tourism. This paper represents a starting point for further research by the author.
\end{abstract}

Keywords wine tourism, wine route, Constantinople wine route, Emperors wine route

\section{INTRODUCTION}

Wine routes are designated tourist routes intended for easier orientation of tourists and as such represent a synonym for trips from winery to winery, wine tasting, enjoying in local gastronomic offer, as well as in sightseeing of other tourist attractions. Wine routes significantly influence the branding of a specific wine region, increasing direct sales revenue both in winery and in other businesses in a given territory. Creating a new wine route involves a number of activities such as: defining the route itself, road signs, arranging the space for reception of guests, expanding the tourist offer, defining hotel management and accommodation capacities, promoting, etc. Benefits from the existence of wine routes are multiple (Marzo-Navarro and Pedraja-Iglesias, 2009; Demonja and Mesarić Žabčić, 2011; Lanfranchi and Dragulanescu, 2013; Galletto, 2018): it enriches the tourist product, creates greater involvement of people in rural areas, extends the 
ToSEE - Tourism in Southern and Eastern Europe, Vol. 5, pp. 419-430, 2019

M. Maksimović, T. Pivac, R. Alkier: CONSTANTINOPLE WINE ROUTE - A NEW WINE TOURISM ...

tourist season, brings together natural, cultural, sociological, demographic and production traits in one whole, economic development is faster, customer loyalty is created, it facilitates the promotion of the region, raises the image, revitalizes the village, etc.

The route of the entire Constantinople wine road has been for centuries the main cultural, transport and trade link between Asia and Europe. On this route, Serbia has strategically the most important position, which can be one of the logical explanations of the fact that this area, historically speaking, has often been the scene of a conflict of great world powers. Likewise, we are familiar with the fact that local population in this area was engaged in cultivation of vines even 6,000 years ago. Today, in the same area, hundreds of different vitis vinifera varieties are cultivated. Some of them belong to the category of autochthonous and are characteristic for certain regions of the Constantinople wine route, and in some cases the whole Balkan Peninsula, and there is a large number of plants under the introduced assortment. The CWR route passes through the territories of three Balkan countries: the European part of Turkey, a large part of Bulgaria and through most of Serbia. Apart from the variety of grapes and good wines, CWR also offers an abundance of gastronomic pleasures, some of the most interesting archaeological sites, cultural monuments, religious temples and similar. Nevertheless, perhaps the most important of all is the story that follows every step of Constantinople Wine Road. For that reason, this paper analyses all the factors necessary for the development of a new wine route, with a special accent on the Serbian part of the route. It is certain that wine tourism can be a very important branch of tourism for each country, especially the developing countries (Boyne et al., 2003; Vlachvei and Notta, 2009).

\section{ABOUT CONSTANTINOPLE WINE ROUTE}

Constantinople road was built by the Romans in 33 A.D. and named Via Militaris. However, it played the most important role in the Middle Ages as a main trade route connecting Asia and Europe. The road was used by armies, caravans, travel writers, pilgrims, bandits...the Turks walked along the same road to conquer Europe, and before them also the Romans who brought the first vine seedlings to the old continent. Today, on major part of this road there is the highway Belgrade-Nis, the section of one of the most important pan-European transport corridors (Corridor 10) that connects BelgradeNis-Dimitrovgrad-Sofia-Istanbul. People were rarely using this road for pleasure. The motives were various, from trade, military campaigns or to escape the invaders. The Constantinople road was not safe for any of them and there was always a risk that they would not arrive where they wanted to go. As the most widespread vehicle of that time, carriages were used. They could be closed, cart and wagon, and in rare cases, chariots were also used. While the passenger carriages were exclusively drawn by horses, military and cargo carriages were drawn by draft horses, buffaloes and oxen. Camels were also used for the transfer of cargo. Namely, camels were not unusual appearance in Belgrade until 1867. In 1433, the French travel writer Brentrandron de la Brocciere (De la Brocciere, 2002) travelled along the Constantinople road. In his travel journal, entitled "The Way over the Sea", he noted that "the current Serbian wines are better than the French ones." 
ToSEE - Tourism in Southern and Eastern Europe, Vol. 5, pp. 419-430, 2019

M. Maksimović, T. Pivac, R. Alkier: CONSTANTINOPLE WINE ROUTE - A NEW WINE TOURISM ...

Picture 1: Map of Constantinople Wine Route from Belgrade, Serbia to Sofia, Bulgaria

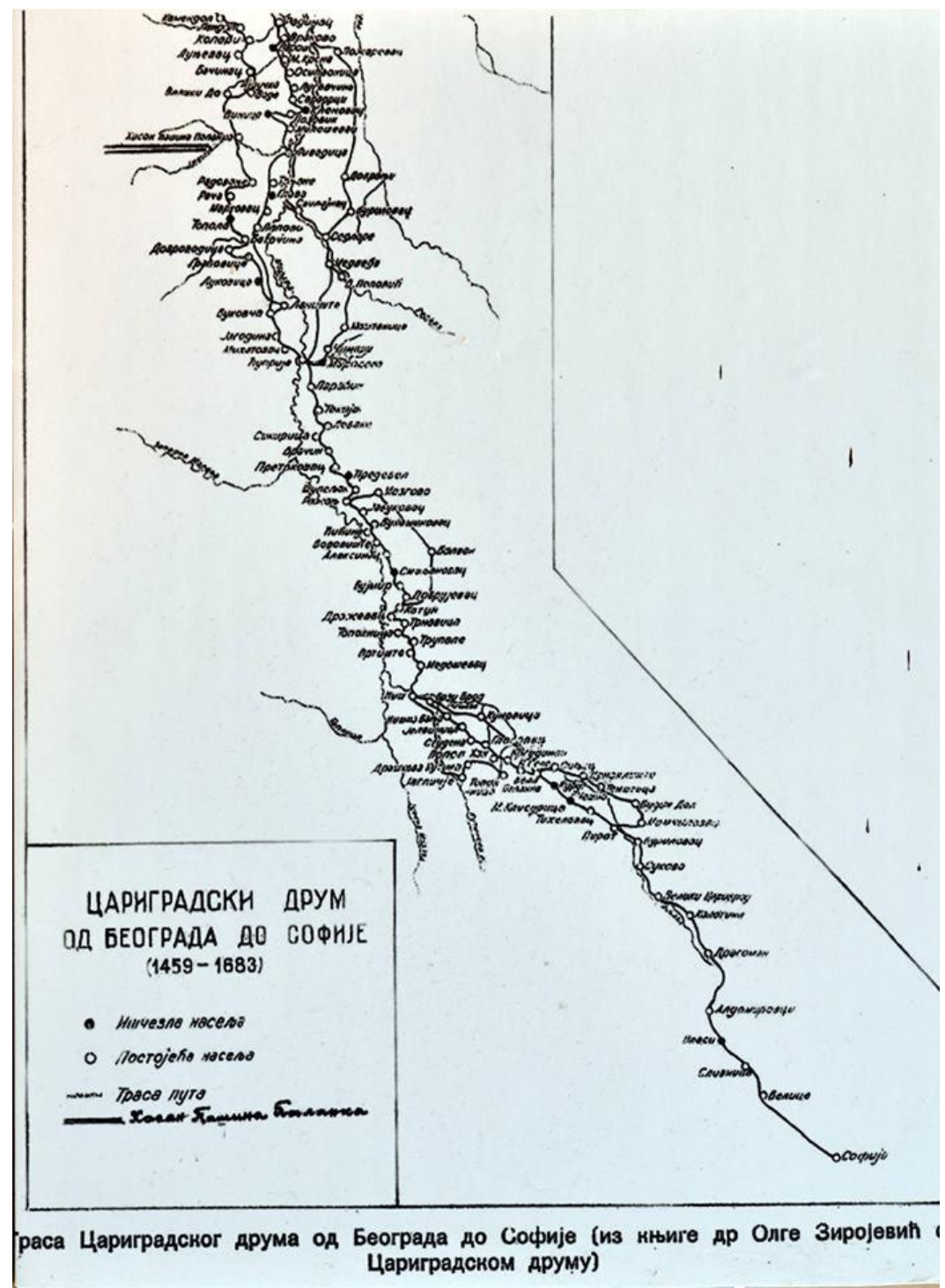

Source: Zirojević, 1970

On the Constantinople wine route there is also the Thracian valley in Bulgaria, which extends to the territory of today's Turkey where it has the same name, Thrace. This part of the route is one of the oldest viticulture regions in the world, about 7000 years old (Ivanova et al., 2017) and it was also listed as one of the best destinations in 2017 according to the magazine "Wine Enthusiasts". The Turkish part of Thrace has its own route called the "Thrace Wine Route", which is also the first wine route in Turkey (Akdag et al., 2017). 
ToSEE - Tourism in Southern and Eastern Europe, Vol. 5, pp. 419-430, 2019

M. Maksimović, T. Pivac, R. Alkier: CONSTANTINOPLE WINE ROUTE - A NEW WINE TOURISM ...

\section{REVIEW OF LITERATURE}

Collective knowledge and awareness of the former military road (Via Militaris), later called the Constantinople Road (Carigradski Drum in Serbian), also known under the names such as Emperors Road (Carski Drum in Serbian), Moravski Road, Big Road, etc, almost does not exist. Neither Serbia nor Bulgaria or Turkey have been recognized by wider public as wine tourist destinations worthy of attention, which represents a huge barrier, but at the same time a potential for the development of a new wine route, such as Constantinople wine road.

Unfortunately, there are few preserved records of everything that was along the route of the Constantinople Road in the past. In recent literature, it almost has not been mentioned at all. Therefore, a great support and base for all further research is found in the works of dr. Olga Zirojevic (Zirojević, 1970), historian and turkologist, who mostly dealt with the topic of the Constantinople road, its history and culture, but also gastronomy during the Turks, as well as the relationship of Turkish authorities towards wine and viticulture in general.

Further, considerable knowledge comes from the travel journals by Evlija Celebija (Celebija, 1957) and Brentrandon de la Brocciere (De la Brocciere, 2002).Bearing in mind that travel journals sometimes have a disputable scientific value (Gvozden, 2014), we still receive a lot of information that, crossed with other sources, can be considered valid, sometimes even very attractive, from the point of creating a specific tourist experience. Important facts are also found in the Vineyard atlas of Serbia (Ivanišević et al., 2015), which lists all the vineyards and presents the latest regions of Serbia, as well as the Wine Atlas (Jakšić et al., 2015) which contains all data on registered wineries and data on the areas of the vineyards of each winery, selection of assortment, production capacity and product range of all wineries. Initial knowledge of wine tourism in general, the history of wine tourism, profiles and types of wine tourist, and similar are found in foreign literature (Hall et al., 2002), but also in monograph Wine Tourism of Vojvodina (Pivac, 2012). Finally, but not less important, a lot of information, experiences and case studies related to the topic of wine tourism are found in works published in various national and international magazines (Akdag et al., 2017; Boyne et al., 2003; Cojocariu, 2015; Hudelson, 2014; Ivanova et al., 2017; Marzo-Navarro, et al., 2009; Salvado, 2016).

The Council of Europe has been working on the certification of cultural routes since 1987. At this moment, there are 33 certified routes (https://www.coe.int/en/web/culturalroutes/home). Each of them is based on the significant historical heritage of a particular region, but at the same time it connects several European countries, respecting the cultural diversity and the tourist offer of each of them. Since 2011, all cultural routes have been grouped into four categories: preservation of cultural heritage, awareness of the importance of cultural heritage, marketing and business development, commercialization of cultural attractions. Currently, each of the 33 cultural routes is considered very important in preservation, care and empowerment of European cultural values. The development of European cultural routes is very important for the expansion of cultural tourism, promotion, and in most cases, of less known destinations, and to a large extent it also focuses on the development of rural areas (Cojocariu, 2015). 
ToSEE - Tourism in Southern and Eastern Europe, Vol. 5, pp. 419-430, 2019

M. Maksimović, T. Pivac, R. Alkier: CONSTANTINOPLE WINE ROUTE - A NEW WINE TOURISM ...

Among these 33 cultural routes, there are also two wine routes:

- Iter Vitis Route (http://www.cittadelvino.it/download.php?file=diane-dodd-itervitis_26.pdf)

- Roman Emperors and Danube Wine Route (http://archive.danubecc.org/upl/RER_brosura_engleski.pdf).

\subsection{Study background}

Speaking about tourism in general, wine tourism as one of the branches has existed for more than 200 years. If we only observe the area of Europe as the original place of creation of the first form of wine tourism: "Austro-Hungarian Emperor Joseph II, passed a legal regulation on August $17^{\text {th }}, 1784$, permitting the sale of wine and food in the vineyards. In time, the vineyards developed the other tourist offer, and everything slowly grew into a unique tourist product" (Pivac, 2012, p. 57). Modern forms of wine tourism and the definition of the first "Wine roads", sometime in the 1920s, became popular in Germany and Austria, and later, in the mid- $20^{\text {th }}$ century, also in the territory of America, France and Australia (Hudelson, 2014).

There are many different definitions of wine tourism (Salvado, 2016) but they can all be summarized in one, according to which wine tourism primarily involves visiting vineyards, wineries and various wine events with the aim of tasting wines and/or discovering the specificity of wines, wine styles and wine assortments of a particular wine region or even the entire region. In addition to tasting and familiarizing the guest with the specifics of a particular wine destination, wine tourism also allows the so-called B2C (business to customer) relationship between the producer and the guest. The B2C approach to wine tourism allows small wineries to survive on a very large and aggressive wine market. Many of them are open all seven days a week and are ready to receive individual guests without prior notice. This is the case with many wineries in America and Australia, and more recently wineries in France (Hudelson, 2014). On the other hand, a large number of wineries in Europe, even those on the route of the Constantinople Wine Road, still prefer pre-scheduled groups of guests. The concept of the announced groups is much more comfortable for the winery. On the other hand, there are more and more individual tourists coming in small groups or by one car to visit the winery. With adequate approach, it is possible to pay more attention to such a guest, and therefore also get better results of wine tourism, where we primarily think of a satisfied client, a guest who stays longer and therefore spends more money. Such approach gives the guest greater independence, which can again affect the higher income of the whole region, since such guests look for accommodation near the winery, which again increases visits to restaurants, museums, galleries, archaeological sites, monasteries and other tourist attractions. When it comes to experiences of wineries along the route of Constantinople Wine Route, we can say that in most cases they are oriented to pre-scheduled groups of tourists, but experience shows that they are increasingly open for individual visits, resulting in higher number of visits. This, of course, means for the winery an additional investment in the recruitment of new staff that will have the knowledge and be able to cope with this new challenge. On the other hand, apart from the covered costs of visiting wineries and wine tasting, this means higher income for the winery form direct wine sales. For small wineries this is one of the most important benefits of wine tourism, while 
ToSEE - Tourism in Southern and Eastern Europe, Vol. 5, pp. 419-430, 2019

M. Maksimović, T. Pivac, R. Alkier: CONSTANTINOPLE WINE ROUTE - A NEW WINE TOURISM ...

with large producers it is a powerful marketing tool that they will use to "tie up" customer to them and convince him/her that such wines are ideal for everyday consumption, which will slightly increase direct sales but will significantly influence the trade in retail shops.

The current situation on the route of Constantinople wine route indicates that more than $70 \%$ of all wineries, when it comes to wine tourism, function according to the principle of pre-scheduled visits, but also that they are becoming more open and prepared for individual visits, especially in the days of weekends and in the summer months.

\subsection{Criteria for measuring performance in wine tourism}

One of the leading researches in wine tourism $(\mathrm{Getz}, 2000)$ suggests several criteria for the development of a wine tourist destination: road infrastructure, sufficient number of wineries in a certain region, the existence of hotel management and accommodation capacities, educated staff, stable political and legal environment, as well as rich historical heritage. Addressing the potentials for the development of wine tourism in the Balkans, John E. Hudelson (Hudelson, 2014) puts these criteria into a broader framework that opens some of the following questions:

- Is there a long and significant tradition of wine production in a particular country?

- What is the attitude of the state towards the wine industry?

- How far are the wine regions away from the capital and other tourist attractions?

- To what extent in economical sense is "healthy" wine industry?

- What is the total national infrastructure like (roads, road signs, mobile and internet network, connection with other countries in Europe and the world, etc.)?

- Quality of hotel management services and other types of accommodation?

- Are there professional organizations, wine events, festivals, etc.?

- How educated are the employees in wineries?

- $\quad$ Do employees in wine tourism speak foreign languages?

Among things that are difficult to measure and put into some logical frameworks, and which can be of decisive importance in measuring the performance of wine tourism are also attentiveness, attitudes and openness of the local population towards wine tourism and entrepreneurship in general. Also, one of the great enemies of success is passivity, and sometimes unrealistic expectations from the state and local authorities.

\section{METHOD OF COLLECTING AND DATA PROCESSING}

For the purpose of writing this paper, a survey was conducted using the method of semistandardized interviews with owners or managers of 53 wineries on the route of the Constantinople Wine Route, that are potential partners in the project of establishing a new wine route. Authors mainly used open type of questions to stimulate long and content response because wanted to get as much information as possible. For example, five questions were used when wanted to know more about motivations and expectations from wine tourism, another seven questions about kind of services which wineries offer to the guests, menu content, wine technology etc. Six, short questions were also used for concrete answers about working time, number of employees in wine tourism segment, 
ToSEE - Tourism in Southern and Eastern Europe, Vol. 5, pp. 419-430, 2019

M. Maksimović, T. Pivac, R. Alkier: CONSTANTINOPLE WINE ROUTE - A NEW WINE TOURISM ...

number of tourists per year, production volume and vineyard area (ha) and grape varieties. There was only one question with closed type of answer: Do you want to be part of CWR project?

This method of data collection, although at first glance it does not have the power of quantitatively stronger research, gives a qualitatively better insight into the state of affairs, while simultaneous covering $100 \%$ sample of respondents. In this way it also easily and spontaneously opens new topics and areas of research, while at the same time allows the respondent to get some useful advice from the researchers for further work and development of tourist potentials.

\section{RESULTS}

These interviews gave a lot of details about wineries all along the Constantinople wine route. Thanks to this research, authors have all strategically important data needed to develop this new Balkan wine and cultural route. Now authors know that some of the wineries have the necessary capacities for the development of wine tourism, some are in preparation and will soon be ready for the reception of the first tourists, and some currently do not have the desire or opportunities for developing tourism potentials. Capacities for wine tourism are primarily the existence of wine cellar, and if possible, the vineyards that can be visited, as well as the tasting room and toilet for the guests of the wine cellar. Smaller wineries which fulfil the above criteria have also been included in the offer. The fact is that small wineries cannot offer guests a superior service, luxury and prestige in the manner of presenting their wineries, but they offer that unique feeling of warmth and often family heritage, so typical for small business.

Table 1: Review of the most important wineries on the route and their tourist potentials

\begin{tabular}{|c|c|c|c|c|c|c|c|}
\hline $\begin{array}{l}\text { Winery } \\
\text { Plavinci } \\
\text { SR }\end{array}$ & $X$ & $X$ & & $X$ & & $X$ & $X$ \\
\hline $\begin{array}{l}\text { Winery } \\
\text { Jeremic SR }\end{array}$ & $X$ & $X$ & $X$ & $X$ & $X$ & $X$ & $X$ \\
\hline $\begin{array}{l}\text { Winery } \\
\text { Janko SR }\end{array}$ & $X$ & $X$ & $X$ & $X$ & & $X$ & $X$ \\
\hline $\begin{array}{l}\text { Winery } \\
\text { Despotika } \\
\text { SR }\end{array}$ & $X$ & $X$ & $X$ & $X$ & $X$ & $X$ & $X$ \\
\hline $\begin{array}{l}\text { Winery } \\
\text { Virtus SR }\end{array}$ & $X$ & $X$ & $X$ & $X$ & & $X$ & $X$ \\
\hline $\begin{array}{l}\text { Winery } \\
\text { Casa vina } \\
\text { iprica SR }\end{array}$ & $X$ & $X$ & $X$ & $X$ & & $X$ & $X$ \\
\hline
\end{tabular}


ToSEE - Tourism in Southern and Eastern Europe, Vol. 5, pp. 419-430, 2019

M. Maksimović, T. Pivac, R. Alkier: CONSTANTINOPLE WINE ROUTE - A NEW WINE TOURISM ...

\begin{tabular}{|c|c|c|c|c|c|c|c|}
\hline $\begin{array}{l}\text { Winery } \\
\text { Todorovic } \\
\text { SR }\end{array}$ & $X$ & $X$ & & $X$ & & & $X$ \\
\hline $\begin{array}{l}\text { Cellar } \\
\text { Jovanovic } \\
\text { SR }\end{array}$ & $X$ & $X$ & & $X$ & & $X$ & $X$ \\
\hline $\begin{array}{l}\text { Cellar } \\
\text { Madzic SR }\end{array}$ & $X$ & $X$ & $X$ & $X$ & & & \\
\hline $\begin{array}{l}\text { Winery } \\
\text { Ambelos } \\
\text { SR }\end{array}$ & $X$ & $X$ & $X$ & $X$ & $X$ & $X$ & $X$ \\
\hline $\begin{array}{l}\text { Winery } \\
\text { Radovanov } \\
\text { ic SR }\end{array}$ & $X$ & $X$ & $X$ & $X$ & & $X$ & $X$ \\
\hline $\begin{array}{l}\text { Cellar } \\
\text { Malca SR }\end{array}$ & $X$ & $X$ & $X$ & $X$ & & $X$ & $X$ \\
\hline $\begin{array}{l}\text { Winery } \\
\text { Lastar SR }\end{array}$ & $X$ & $X$ & & $X$ & & & $X$ \\
\hline $\begin{array}{l}\text { Winery } \\
\text { Rubin SR }\end{array}$ & $X$ & $X$ & $X$ & $X$ & & & $X$ \\
\hline $\begin{array}{l}\text { Winery } \\
\text { Cilic SR }\end{array}$ & $X$ & $X$ & $X$ & $X$ & & & \\
\hline $\begin{array}{l}\text { Winery } \\
\text { Temet SR }\end{array}$ & $X$ & $X$ & $X$ & $X$ & & & $X$ \\
\hline $\begin{array}{l}\text { Winery } \\
\text { Piano SR }\end{array}$ & $X$ & $X$ & $X$ & $X$ & & $X$ & $X$ \\
\hline $\begin{array}{l}\text { Winery } \\
\text { Savic SR }\end{array}$ & $X$ & & & $X$ & & & \\
\hline $\begin{array}{l}\text { Winery } \\
\text { Aleksic SR }\end{array}$ & $X$ & $X$ & $X$ & $X$ & & & $X$ \\
\hline $\begin{array}{l}\text { Manastira } \\
\text { Boutique } \\
\text { Wine } \\
\text { Cellar BG }\end{array}$ & $X$ & $X$ & $X$ & $X$ & & & $X$ \\
\hline $\begin{array}{l}\text { Villa } \\
\text { Yustina } \\
\text { BG }\end{array}$ & $X$ & $X$ & $X$ & $X$ & $X$ & $\mathrm{X}$ & $X$ \\
\hline $\begin{array}{l}\text { Villa } \\
\text { Vinifera } \\
\text { Winery BG }\end{array}$ & $X$ & $X$ & $X$ & $X$ & & & $X$ \\
\hline $\begin{array}{l}\text { Rumelia } \\
\text { Winery BG }\end{array}$ & $X$ & $X$ & $X$ & $\mathrm{X}$ & & & $X$ \\
\hline $\begin{array}{l}\text { Bendida } \\
\text { Winery BG }\end{array}$ & $X$ & $X$ & $X$ & $X$ & & $X$ & $X$ \\
\hline $\begin{array}{l}\text { Villa } \\
\text { Bassarea } \\
\text { BG } \\
\end{array}$ & $X$ & $X$ & $X$ & X & & & \\
\hline
\end{tabular}


ToSEE - Tourism in Southern and Eastern Europe, Vol. 5, pp. 419-430, 2019

M. Maksimović, T. Pivac, R. Alkier: CONSTANTINOPLE WINE ROUTE - A NEW WINE TOURISM ...

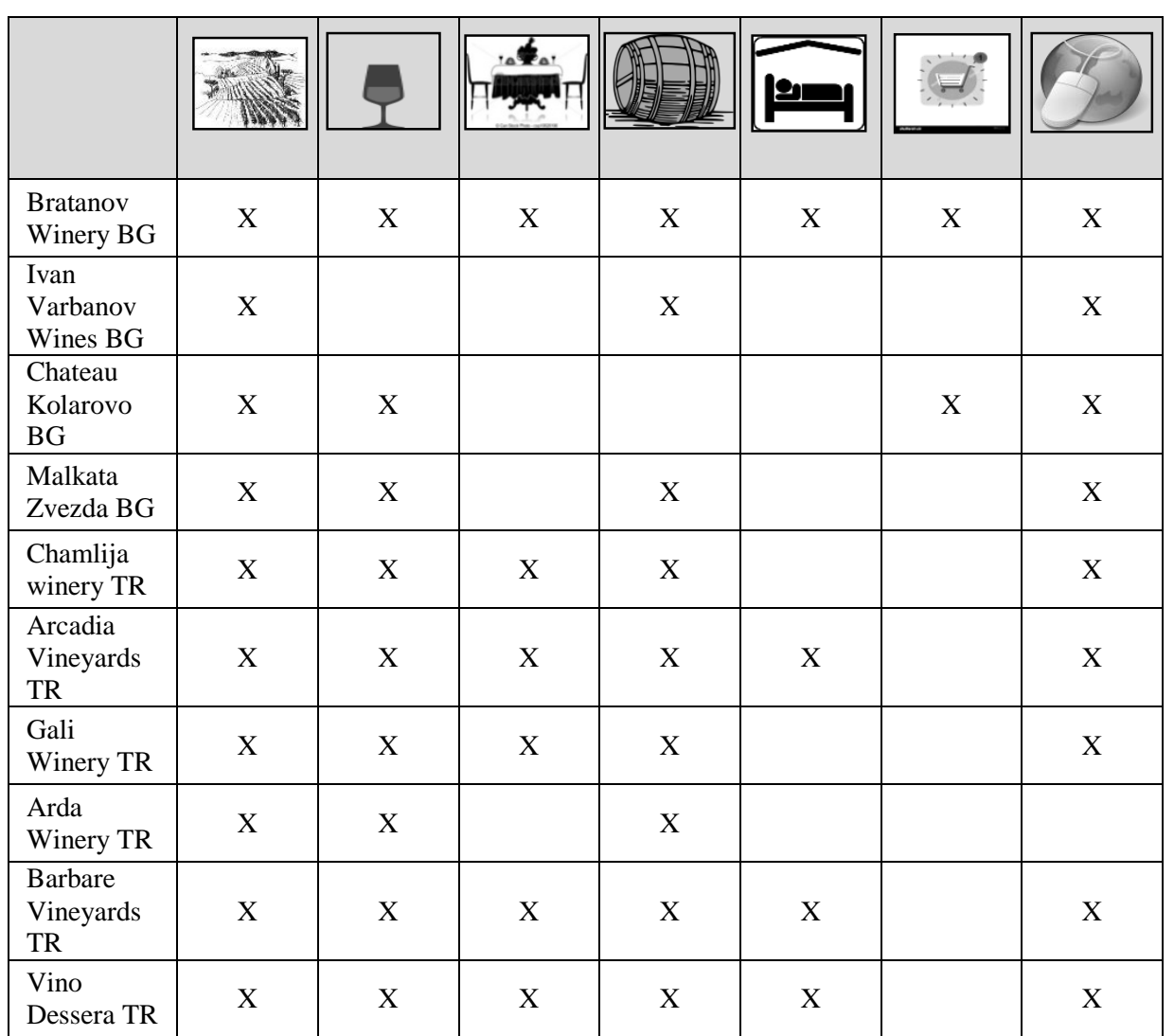

Legend

\begin{tabular}{|c|c|c|}
\hline \multirow{3}{*}{$\sqrt{x / 4}$} & - & Own vineyard \\
\hline & - & Wine tasting \\
\hline & - & Degustation hall \\
\hline & - & Own cellar \\
\hline & - & Possibility of accommodation \\
\hline o & - & internet wine selling \\
\hline & - & website \\
\hline
\end{tabular}


ToSEE - Tourism in Southern and Eastern Europe, Vol. 5, pp. 419-430, 2019

M. Maksimović, T. Pivac, R. Alkier: CONSTANTINOPLE WINE ROUTE - A NEW WINE TOURISM ...

\section{CONCLUSIONS AND RECOMMENDATIONS}

Looking at the whole Constantinople Wine Route, it can be concluded that different parts of the route provide various contents when wine tourism and wine offer are concerned. It is interesting that in some parts of the route there are not even wineries that could be visited, but there are plenty of other interesting tourist facilities, such as the workshop of Pirot rugs or frescoes of the Sukovo monastery, for example. In the area around Pirot there is also an interesting hotel management facility that has a good selection of wine and accommodation capacities, and thus can compensate for the lack of wineries. In addition, the gastronomy of this region is highly appreciated and as such very attractive for tourists to whom gastronomy is not the primary motive for travel.

The Constantinople wine route is rich in good and worldwide award-winning wines, which is extremely important for professionals and top wine experts. Such visitors always come announced either individually or in small groups, so it is certain that they will be adequately welcomed in every winery, even if they are foreigners. The infrastructure of Constantinople wine road can be considered acceptable, though not ideal. Access roads are often not in best condition but are regularly maintained and passable. The mobile and internet signals are quite good, which is very important nowadays. Road signs could be better, especially if you take into account wineries that have been established in the past few years and have no signs.

A stable political and monetary situation is very important for both domestic and foreign tourists. Also, the good mutual relations of countries which host CWR are important.

Nevertheless, the greatest strength and potential of the Constantinople Wine Route lies in rich cultural heritage and historical significance. Traces of the Ottoman Empire on the Balkans have been preserved in material form, but also in collective memory. Part of this culture lives even today and is reflected in written and spoken language filled with words of Turkish origin, gastronomy and viticulture.

By careful consideration of the Constantinople Wine Route and its potential for developing a new wine route, it is concluded that this project has a great chance to become a wine tourism project of international importance for several reasons:

1. It is based on the promotion and values of rich cultural and historical heritage

2. Some of the best wineries in Serbia, Bulgaria and Turkey are on the CWR route

3. Wines originating in wineries on the CWR route are often also wines that are exported and as such make the route recognizable as significant wine destination

4. Since some wines are already on different markets in the world, it's much easier to organize promotions abroad

5. The most important viticulture regions are only an hour drive from the big centres, which is important for the success of wine tourism

6. These are the best equipped infrastructure sections of Serbia, Bulgaria and Turkey

7. Thanks to a private initiative, the Constantinople Wine Route requires only an investment in marketing 
ToSEE - Tourism in Southern and Eastern Europe, Vol. 5, pp. 419-430, 2019

M. Maksimović, T. Pivac, R. Alkier: CONSTANTINOPLE WINE ROUTE - A NEW WINE TOURISM ...

8. Once the route from Belgrade to Istanbul is established, the same model can be applied to the creation of a new wine route that will go north (the final destination of Vienna) and which will be called the Emperors Wine Route (Carski vinski drum in Serbian). Both names, Constantinople Wine Route and Emperors Wine Route are already protected, and the marketing presentation takes place in phrases. Creation, planning, management, finances and realization of tourist programs are fully entrusted to the PanaComp and Kompas companies from Novi Sad.

Having in mind all the weaknesses that really exist, it is now important to establish rules and relationships among all participants in the project. This would contribute to establishing a healthy relationship among stakeholders that could turn the majority of weaknesses into advantages. Because the team is as strong as its weakest link is strong (Maksimović, 2006).

As it can be observed from the above mentioned, the results of this research confirm the thesis that wine tourism has future in Serbia. Wine tourism is considered an important segment that has not yet been sufficiently utilized and it should be given more attention. Private initiative for now gives more than good results, so it would be quite realistic to expect the competent state institutions to put wine tourism among the priorities in the development of each country on the CWR route. It would be the main precondition for greater support of state authorities, primarily in improving the infrastructure necessary for the growth and development of wine tourism.

\section{REFERENCES}

Akdag, G., Oyan, S., Kastenholz, E. (2017), "Motivators for participating in Wine Tourism Activities - the case of Tourists on the Thace Wine Route in Turkey", Revista Turismo \& Desenvolvimento, No.27/28, pp. 85-87.

Boyne, S., Hall, D., Williams, F. (2003), "Policy, support and promotion for food-related tourism initiatives: A marketing approach to regional development", Journal of Travel \& Tourism Marketing, Vol. 14, No. 3-4, pp. 131-154.https://doi.org/10.1300/J073v14n03_08

Cojocariu, S. (2015), "The development of cultural routes: a valuable asset for Romania", Procedia Economics and Finance, Vol 32, pp. 959-967, DOI: 10.1016/S2212-5671(15)01554-3

Council of Europe; https://www.coe.int/en/web/cultural-routes/home: 25.01.2019.

Celebi, E. (1967), Travel Journal.Svjetlost, Sarajevo.

Demonja, D., Mesarić Žabčić, R. (2011), "Wine Road in the Development of Rural Tourism of North Western Croatia: Medjumurje Wine Road as good Practice Example”, Enometrica, Vol. 4, No. 2, pp. 59-73.

Galletto, L. (2018), "A comparison between tourists` profiles in two Italian wine routes", Revista de la Facultad de Ciencias Agrarias, Vol. 50, No.1, pp.157-170.

Getz, D. (2000), Explore wine tourism: management, development, destinations. Cognizant, New York.

Gvozden, V. (2014), How to read travel journal, http://bif.rs/2014/05/vladimir-gvozden-kako-citati-putopis: 26.12.2018.

Hall, M., Sharples, L., Cambourne, B., Macionis, N. (2010), Wine Tourism around the World. ButterworthHeinemann, Oxford

Hudelson, J. (2014), "Eastern Promises: The potential Future for Wine Tourism in the Balkans”, American Journal of Tourism Management, 3(IB), pp. 34-50, DOI: 10.5923/s.tourism.201402.05

Ivanišević, D., Jakšić, D., Korać, N. (2015), Vineyard atlas. Republican Bureau of Statistics, Belgrade.

Ivanova, S., Kireva, K., Dimitrov, D. (2017), "On the way to the Thracian wine", Journal of Mountain Agriculture on the Balkans, Vol. 20, No. 4, pp. 168-177.

Jakšić, D., Ivanišević, D., Djokić, V., Brbaklić Tepavac, M. (2015), Vineyard atlas, Republican Bureau of Statistics, Belgrade. 
ToSEE - Tourism in Southern and Eastern Europe, Vol. 5, pp. 419-430, 2019

M. Maksimović, T. Pivac, R. Alkier: CONSTANTINOPLE WINE ROUTE - A NEW WINE TOURISM ...

Lanfranchi, M., Dragulanescu, C. (2013), “A New Economic Model for Italian Farms: The Wine \& Food Tourism”, Journal of Knowledge Management, Economics and Information Technology, Special Issue/December, pp. 222-235

Maksimović, M. (2006), Team work in new millennia. Cekom books and Faculty of management, Novi Sad.

Marzo-Navarro, M., Pedraja-Iglesias, M. (2009), "Wine tourism development from the perspective of the potential tourist in Spain", International Journal of Contemporary Hospitality management, Vol. 21, No. 7, pp. 816-835. https://doi.org/10.1108/09596110910985304

Pivac, T. (2012), Wine tourism of Vojvodina, University of Novi Sad - Faculty of Sciences, Department of geography, tourism and hotel management, Novi Sad.

The list of agriculture: http://popispoljoprivrede.stat.rs: 16.01.2019.

Salvado, J. (2016), Wine culture, territory/landscape and tourism, the enotourism key pillars. How to get business success and territorial sustability inside wine tourism ecosyste? APTUR - Associacao Portuguesa de Turismologia.

Vlachvei, A., Notta, O. (2009), "Wine Routes in Greece: Producers` Perceptions and Economic Implications", International Journal of Arts and Sciences, Vol. 3, No. 2, pp. 95-106.

Zirojević, O. (1970), "Constantinople road from Belgrade to Sofija (1459-1683)", The Collection of Historical museum of Serbia 7, Beograd.

https://www.coe.int/en/web/cultural-routes/home

http://archive.danubecc.org/upl/RER brosura_engleski.pdf

http://www.cittadelvino.it/download.php?file=diane-dodd-iter-vitis_26.pdf

Mirjana Maksimović, MSc in Scientific Area Management

Association Women and Wine

Kumodraška 114, Belgrade, Serbia

Phone: +38163515830

E-mail: zeneivino.ns@gmail.com

Tatjana Pivac, $\mathrm{PhD}$, Associate Professor

University of Novi Sad, Faculty of Sciences

Department of Geography, Tourism and Hotel Management

Trg Dositeja Obradovića 3, Novi Sad, Serbia

Phone: +381641759344

E-mail: tatjana.pivac@dgt.uns.ac.rs

Romina Alkier, $\mathrm{PhD}$, Associate Professor

University of Rijeka

Faculty of Tourism and Hospitality Management

Primorska 42, 51410 Opatija, Croatia

Phone: +385 51294718

E-mail: rominaa@fthm.hr 